\title{
Tutors' perceptions about science curriculum reforms and challenges for their implementation in Teacher Training Colleges in Rwanda
}

\author{
C. Kanamugire ${ }^{1}$, L.L. Yadav ${ }^{2}$ and A. Mbonyiryivuze ${ }^{3}$
}

\begin{abstract}
This paper reports science tutors' perceptions about science curriculum reforms occurred in Rwanda from 1996 to 2013 in Teacher Training Colleges (TTCs). It also highlights their perceptions about challenges and factors for effective implementation of Integrated Science Curriculum (ISC). Data for the study were collected from 26 science tutors teaching ISC in 11 TTCs from 4 provinces using questionnaires and structured interviews. Results showed that a slim majority of science tutors were not resistant to curriculum reform. Even if most of science tutors were confident while teaching most of the topics in ISC, they have experienced some difficulties in teaching physics and cross-cutting domains related topics as well as practical activities. Other identified challenges include lack of qualified tutors to teach ISC in TTCs, insufficient contact hours allocated to ISC topics, tutors' heavy workload, lack of sufficient science laboratory equipment and materials. In addition to TTC libraries that are not well equipped, lack of textbooks and teacher's guides as well as lack of in-service tutors' trainings were stressed to be some of challenges. Even if it was found that most competencies, skills, knowledge and attitudes gained by student-teachers after completing ISC were highly rated by science tutors, communication skills and problem-solving skills that are claimed to be important skills needed by graduates of science in the workplaces were poorly rated. The recommended strategies to overcome the identified challenges include active involvement of TTCs' science tutors in designing and development of ISC. Moreover, all TTCs should be provided with qualified science tutors to teach ISC. Trainings for in-service science tutors, recruitment of qualified tutors, and provision of adequate facilities, libraries and well-equipped science laboratories for all TTCs are also recommended.
\end{abstract}

Key words: $\quad$ curriculum reforms; integrated science curriculum; teacher training colleges; tutors' perception

\section{Background of the study}

Curriculum is defined as the vehicle through which a country empowers its citizens with the necessary knowledge, skills, attitudes and values empowering them for personal and national development (Kabita \& Ji, 2017). Thus, any curriculum should meet the needs of the individual citizens and the nation. There is an imperative need of a regular curriculum updates for its adequacy, relevance and coherence in order to keep pace with the changing global situation (REB, 2015). In

\footnotetext{
${ }^{1}$ Camille Kanamugire is the Director of Mathematics and Science Subjects Question Item Bank Unit, Rwanda Education Board, Kigali, Rwanda. Email: ckanamugire2001@yahoo.fr

${ }^{2}$ Lakhan Lal Yadav is the Director of the African Centre of Excellence for Innovative Teaching and Learning Mathematics and Science (ACEITLMS), University of Rwanda- College of Education, Rukara Campus, Rwanda. Email: yadavll@yahoo.com

${ }^{3}$ Agnes Mbonyiryivuze is a PhD student in Physics Education at the African Centre of Excellence for Innovative Teaching and Learning Mathematics and Science (ACEITLMS), University of Rwanda- College of Education, Rukara Campus, Rwanda. Email: mbonyiryivuzeagnes@yahoo.com, +250785820176

Open Access article distributed under the terms of the Creative Commons Attributions License [CC BY-NC-ND 4.0] http://creativecommons.org/licenses/by-nc-nd/4.0. DOI: https://dx.doi.org/10.4314/ajesms.v15i1.9
} 
Tutors' perceptions about science curriculum reforms and challenges for their implementation in Teacher Training Colleges in Rwanda

C. Kanamugire, L.L. Yadav and A. Mbonyiryivuze

Africa, different curriculum reforms faced challenges during implementation as reported in UNICEF think piece series: Curriculum reforms (Cunningham, 2018).

The science curriculum has been gone through different reforms globally in order to improve its quality as it has been reported in literature and science development efforts were initiated during the 1960s after the sudden launching of Sputnik by Soviet Union in 1957 (Park, 2006; Dillon, 2009; Atkin \& Black, 2010; Meltzer \& Otero, 2015; Mbonyiryivuze, Kanamugire, Yadav, \& Ntivuguruzwa, 2018). The science curriculum reforms were also carried out various countries in Africa including South Africa, Rwanda, Botswana, etc. (Bantwini, 2010; Erduran \& Msimanga, 2014; Cunningham, 2018).

In Rwanda, the curriculum was revised in 1996 to suit the needs of the diversity of students enrolled in different schools and to harmonize the existing curricula which were taught in different schools (MINEDUC, 1997). The teacher training school reforms started with the academic year 1998/1999 and then phasing out the old system up to the year 2000/2001. The teacher training school options were replaced by Teacher Training Colleges (TTCs) which became exclusively pre-service and inservice teacher training colleges. Trainers in these TTCs are known as tutors. In 1998, TTCs were assigned exclusively the mission to offer pre-service training for primary teachers. With this reform, TTCs remained with only upper secondary level: Senior four (S4), Senior Five (S5) and Senior Six (S6) and their curricula were revised to ensure professionalism and specialization. With the curriculum review occurred in 2008, the pre-service training was more professionalized with introduction of three combinations within TTCs. The introduced combinations were Teaching Science and Mathematics (TSM), Teaching Social Studies (TSS) and Teaching Modern Languages (TML). This curriculum became operational by the academic year 2009 (MINEDUC, 2009). The change in curriculum for TTCs aimed at improving the training of future teachers at primary level with the focus on content and teaching methodology for the subjects to be taught at primary schools. After completing their teacher training, TTC leavers are awarded a Primary Teacher Education Certificate subject (Uworwabayeho \& Muhire, 2016). As science and technology is one of the areas of priority in the Rwanda education sector, well trained student-teachers by science tutors at TTCs are needed to enhance the teaching of Science and Technology at primary education level. These student-teachers are those enrolled in TSM combination. One of the curricula introduced in 2011 for that combination is ISC, which prepares student-teachers to teach Science and Elementary Technology (SET) at primary school (KIE, 2011). Tutors are likely the first implementers of this new curriculum. Therefore, for the effective implementation of ISC, they should be involved and feel committed to implement it.

In Rwanda, studies have been silent on the importance of tutors' perceptions about curriculum reforms specifically in TTCs, their involvements in curriculum design and development, challenges faced while implementing the new curriculum as well as their perceptions about factors hindering its effective implementation (Uworwabayeho \& Muhire, 2016; Ndihokubwayo, 2017; Ndihokubwayo, Uwamahoro, \& Ndayambaje, Rwanda, 2018). According to Mbonyiryivuze et al. (2018), for a curriculum reform to be useful in school context, its implementation strategies must be sufficiently flexible and care should be taken for the details of individuals, classroom and school environment. It is also necessary that teachers feel to be part of the curriculum for more commitment (Mbonyiryivuze, Kanamugire, Yadav, \& Ntivuguruzwa, 2018) as their perceptions about curriculum reform will reflect through its implementation. In this period of long-term development of new curricula, it was crucial to find out tutors' perception about these reforms, challenges for 
curriculum implementation, hindering its effective implementation as well as strategies facilitating its implementation. Teachers' participation in curriculum design is highlighted in most studies with little focus on the challenges faced by them while trying to be part of the curriculum design process (Abudu \& Mensah, 2016). Therefore, it is important to find out tutors' perception about their involvements in curriculum design and development, their perceptions about curriculum reforms in TTCs, challenges faced while implementing the new curriculum as well factors hindering its effective implementation.

This paper discusses results on science tutors' perceptions about science curriculum reforms in TTCs in Rwanda from 1996 to 2013. It discusses demographic profiles of science tutors participated in the study, their perceptions on science curricular reform especially for ISC. Additionally, science tutors' perceptions about factors and challenges for effective implementation of ISC as well as some strategies to be used to facilitate the implementation are reported. In this paper, some recommendations that may be taken into consideration for effective implementation of ISC especially in TTCs are provided.

\section{Methodology}

Data presented in this article were collected as a part of a study on teachers' perceptions about science curriculum changes that occurred in TTCs in Rwanda from 1996 to 2013 and challenges hindering the implementation of ISC. The research was conducted in 13 TTCs from four Rwandan provinces: 3 TTCs, 2 TTCs, 4 TTCs, and 4 TTCs from Eastern, Northern, Southern and Western provinces, respectively. Science tutors were selected for this study purposively and according to their availability at the TTCs. In fact science tutors who were not at the TTC on the day of administration of questionnaire and interview didn't participate in the study. Moreover, the time, financial constraints as well as the location of TTCs across the country were other factors which influenced our data collection. The population of the study was composed of all tutors in 13 TTCs estimated to be 259 tutors. Data collection was done through questionnaire supplemented by structured interview. Questionnaires were completed by 26 tutors from 11 TTCs. Only 16 science tutors from 9 TTCs out of 11 TTCs participated in the interview. The questionnaire containing 16 closed ended questions was designed and was guided by research questions and literature review. Collected data using questionnaire were analysed using descriptive statistics while those from interviews were analysed using qualitative analysis. Descriptive statistics analysis was carried out using Statistics Package for Social Studies (SPSS).

\section{Results and discussions}

In this section, after providing demographics of participated sciences tutors, findings and their corresponding discussion on tutors' perceptions about science curriculum reform and challenges hindering its implementation are reported. Additionally, science tutors' perceptions about factors affecting the implementation of ISC and potential strategies to overcome challenges for the effective implementation of ISC in TTCs.

\section{Demographics of science tutors}

In order to provide a context for data view, science tutors demographics are presented for gender, qualifications, age group, years of teaching experience as well as subject of specialization or combination. The gathered demographics of science tutors are discussed in terms of gender and qualifications, specialization or combination, age group and experience. 
Tutors' perceptions about science curriculum reforms and challenges for their implementation in Teacher Training Colleges in Rwanda

C. Kanamugire, L.L. Yadav and A. Mbonyiryivuze

For this study, $21(80.8 \%)$ science tutors involved in the study were males and $5(19.2 \%)$ science tutors were females. Even if the Teacher Development and Management (TDM) policy highlights the need to ensure absence of major gender disparities at each level of the teaching force in teachers' recruitment (MINEDUC, 2007), these science tutors were male dominated. About science tutors qualifications, $16(61.5 \%)$ science tutors hold A0 with education (equivalent to bachelor's degree), $6(23.1 \%)$ science tutors hold A0 without education while $4(15.4 \%)$ science tutors hold A1 with education (equivalent to diploma). These findings are not in agreement with the TDM policy stipulating that an upper secondary school teacher must have completed six years of secondary education and undertaken a four-year program in university including teaching practice (MINEDUC, 2007; General Inspectorate of Education, 2009). The Ministry of Education of Government of Rwanda emphasized that tutors allowed for teaching in TTCs should have earned a Bachelor of Education degree from a recognized and accredited institution in a specific subject with specialization in Primary Teacher Education (MINEDUC, 2014). Therefore, the above findings show that there was a significant gap between the qualification of science tutors involved in the study and what was required for TTCs science tutors.

Table 1: Science tutors' subject of specialization or combination

\begin{tabular}{lll}
\hline Subject of specialization & Frequency & Percent \\
\hline Integrated Science & 2 & 7.7 \\
Biology & 2 & 7.7 \\
Chemistry & 6 & 23.1 \\
Physics & 3 & 11.5 \\
Biology \& Chemistry & 6 & 23.1 \\
Mathematics \& Physics & 3 & 11.5 \\
Physics \& Chemistry & 2 & 7.7 \\
Other specialization & 2 & 7.7 \\
Total & 26 & 100.0 \\
\hline
\end{tabular}

Table 1 shows science tutors' different science subjects of specialization or combinations, studied during their programme of study. Only $2(7.7 \%)$ science tutors were specialized in integrated science and are the only ones meeting the requirements to teach integrated science subject in TTCs (MINEDUC, 2014). Science tutors specialized in chemistry and/or biology, biology and chemistry were $14(53.8 \%)$ while those specialized in physics and/or Mathematics and physics and chemistry were $8(30.8 \%)$. Two science tutors $(7.7 \%)$ were qualified in other domains than those taught in University of Rwanda- College of Education. Those domains were Electronics and Telecommunications and Food Science.

Looking at respondents' age group and teaching experience, 17 (64.4\%) out of 26 science tutors were less than 35 years. This is an indication that a large number of science tutors were still young. Only one (1) science tutor (3.8\%) was less than 25 years, the same percentage for the most aged science tutor. From results, it can be seen that 13 science tutors $(50 \%)$ had taught less than 4 years while 7 science tutors $(26.9 \%)$ had taught between 5 and 9 years. This is an indication that $76.9 \%$ of science tutors had a teaching experience of less than 10 years. Those with at least 10 years of teaching experience were $6(23 \%)$. 


\section{Science tutors' perceptions about science curriculum reforms in TTCs}

This section reports about teachers' perceptions about major reforms in science curricula that occurred in Rwandan TTCs from 1996 to 2013 and their perceptions about science curriculum reforms in TTCs in general and their perceptions about the extent to which student-teacher's gain of competencies, skills, attitudes and knowledge upon completion of the ISC. Finding about these three issues are going to be discussed below starting with tutors' perceptions about major reforms in science curricula occurred in Rwandan TTCs from 1996 to 2013.

The results about teachers' perceptions on these major reforms on science curriculum were analyzed using a 5 Likert-scale with Strongly Disagree, Disagree, Neutral, Agree and Strongly Agree. The following are results about teachers' perceptions on five major reforms that occurred in Rwandan TTCs' science curriculum.

Table 2: $\quad$ Science tutors perceptions about major reforms occurred in Rwandan TTC's science curriculum from 1996 to 2013

\begin{tabular}{|c|c|c|c|c|c|}
\hline \multirow[b]{2}{*}{ Major reforms in TTC's science curriculum } & \multirow[b]{2}{*}{ Mean } & \multirow[b]{2}{*}{$\mathrm{SD}^{*}$} & \multirow[b]{2}{*}{ Agree } & \multicolumn{2}{|c|}{ Percentage } \\
\hline & & & & Neutral & Disagree \\
\hline $\begin{array}{l}\text { Shift from teaching science as separate subjects } \\
\text { to teaching science as integrated topics }\end{array}$ & 4.23 & 0.815 & 84.6 & 11.5 & 3.8 \\
\hline $\begin{array}{l}\text { Number of periods per week is equally } \\
\text { distributed from year } 1 \text { to year } 3\end{array}$ & 3.77 & 1.451 & 65.4 & 30.8 & 3.8 \\
\hline The format of ISC is well structured & 2.73 & 1.251 & 26.9 & 11.5 & 61.5 \\
\hline $\begin{array}{l}\text { Methods used in teaching ISC are learner- } \\
\text { centered }\end{array}$ & 3.81 & 0.801 & 73.1 & 19.2 & 7.7 \\
\hline $\begin{array}{l}\text { The learning outcomes for student-teacher upon } \\
\text { completion of ISC are more precise }\end{array}$ & 3.88 & 0.909 & 69.2 & 23.1 & 7.7 \\
\hline
\end{tabular}

Table 2 shows results about teachers' perceptions on these five major reforms. The five major reforms are shift from science as separate subjects to teaching science as integrated topics, equal distribution of number of periods per week from year 1 to year 3, the structure of ISC, learnercentered pedagogy as teaching methods for ISC and precision of the learning outcomes for studentteacher upon completion of ISC.

Apart from the structure of ISC, science tutors showed high agreement of $84.6 \%, 65.4 \%, 73.1 \%$ and $69.2 \%$ respectively for other 4 reforms. In fact science tutors' appreciation of those 4 major reforms for TTCs science curriculum but they have shown high level of disagreement on the structured of ISC. The rate of disagreement on the structure of ISC was $61.5 \%$ while the percentage of agree was $26.9 \%$. The finding on the structure of ISC was supported by obtained results from interview where tutors argued that some concepts were well presented in former science curriculum than they are in ISC. They also claimed that the ISC content was very wide and not well distributed across Year 1 to Year 3 of TTCs. Moreover, concerning equal distribution of number of periods per week from year 1 to year 3, the science tutors reported through interview that contact hours allocated to ISC are not sufficient compared to the content to be covered in some topics such as electricity and magnetism, plant and animal life and organic chemistry. In fact, 
Tutors' perceptions about science curriculum reforms and challenges for their implementation in Teacher Training Colleges in Rwanda

C. Kanamugire, L.L. Yadav and A. Mbonyiryivuze

science tutors said that content of ISC is not very different with that of science subjects in other science combinations while number of hours per week for teaching is different and there was no apparent change in science curriculum, only different topics were put together in one document which was named ISC. Moreover, during the interview, the inadequacy between content and contact hours for ISC for TSM combination, lack of adequate integration, lack of link between ISC and Science and Elementary Technology (SET) taught at primary school level, and unequal distribution of contact hours across year 1 to year 3 were highlighted. This trend can be explained by science tutors' qualification and their teaching experience as it has been shown in section of science tutors profiles. It is likely that $23.1 \%$ of science tutors who are not qualified in education are not well informed on how a science curriculum should look like and $50 \%$ of science tutors having less than 4 years of teaching experience less than 4 years are most likely not being familiar with the structure of the curriculum.

The summary of general perceptions of participated science tutors about science curriculum reforms in TTCs is provided in Table 3.

Table 3: $\quad$ General science tutors' perceptions about science curriculum reforms in TTCs

\begin{tabular}{lrrrrc}
\hline & & & \multicolumn{3}{c}{ Percentage } \\
& Mean & SD* & Agree & Neutral & Disagree \\
\hline $\begin{array}{l}\text { I felt comfortable with used curriculum for } \\
\text { TTCs from } 1996 \text { to } 2011 \text {. }\end{array}$ & 2.62 & 1.388 & 30.7 & 15.4 & 53.8 \\
$\begin{array}{l}\text { I worry that some content has been omitted while } \\
\text { changing science curriculum for TTCs }\end{array}$ & 3.12 & 1.479 & 46.2 & 15.4 & 38.4 \\
$\begin{array}{l}\text { I feel that there was a need of science } \\
\text { curriculum reform }\end{array}$ & 2.23 & 1.306 & 19.2 & 15.4 & 65.4 \\
$\begin{array}{l}\text { I feel enthusiastic towards science curriculum } \\
\text { reform for TTCs }\end{array}$ & 3.23 & 1.234 & 46.2 & 26.9 & 26.9 \\
\hline & & & & &
\end{tabular}

Concerning science tutors' perceptions on science curriculum reforms for TTCs in general, the investigated perceptions were about how comfortable science tutor felt with the curricula for TTCs used from 1996 to 2011, their worries about the omission of some content during reform, their feeling about the need of science curriculum reform and their eagerness towards science curriculum reform for TTCs. Regarding general perceptions of participated science tutors about science curriculum reforms in TTCs, majority of science tutors $(53.8 \%)$ showed no resistance to reform of curriculum. In fact, these science tutors have supported curriculum reform. However, a considerable number of science tutors $30.7 \%$ were happy with the old curriculum. Science tutors showed their worries for the omission of some content in curriculum reform at a rate of $46.2 \%$, while $38.4 \%$ had no worries. A significant percentage corresponding to combined levels of 'agree' and 'neutral' was at rate of $61.6 \%$ shows some of these science tutors were not aware of the science curriculum used from 1996 to 2011. This can be explained by the fact that most of science tutors do not have a long experience in teaching as it has been found while looking at their teaching experience. Some science tutors were keen to curriculum reform as it was shown by the percentage of agreement was at rate of $46.2 \%$, while $26.9 \%$ science tutors were not enthusiastic to reform. 
Briefly, findings on general perceptions of science tutors' about science curriculum changes in TTCs are in agreement with literature stating that teachers will either respond to imposed curriculum change by resisting and ignoring the change or modifying the curriculum change (Keys, 2003). It has been also reported that that teachers who did not receive training on the new curriculum changes during their tertiary education feel that there is no need to change their teaching approach (Lizer, 2013). Moreover, the study of Cohen et al. (2012) highlighted the importance of learning about how teachers understand new curricular policies through the lens of older curricular policies. They also argued that whatever novelties curricular innovations embrace, teachers continue to work with the residues of the past (Cohen, Manion, \& Morrison, 2012). Tutors' perceptions about the extent of student-teacher's gain of competencies, skills, attitudes and knowledge upon completion of the ISC are summarized below in Table 4.

Table 4: $\quad$ Science tutors' perceptions about the extent of student-teacher's gain of competencies, skills, attitudes and knowledge upon completion of the ISC

\begin{tabular}{lccccc}
\hline & & & \multicolumn{3}{c}{ Percentage } \\
\cline { 5 - 6 } $\begin{array}{l}\text { Knowledge/competencies/skills/ } \\
\text { attitudes gained by student-teacher }\end{array}$ & Mean & SD* & $\begin{array}{c}\text { Great } \\
\text { extent }\end{array}$ & $\begin{array}{c}\text { Some } \\
\text { extent }\end{array}$ & $\begin{array}{c}\text { Little } \\
\text { extent }\end{array}$ \\
\hline Adequate teaching skills & 3.88 & 0.766 & 73.0 & 23.1 & 3.8 \\
Problem solving skills & 3.62 & 1.061 & 53.9 & 34.6 & 11.5 \\
Scientific inquiry & 3.85 & 0.881 & 69.3 & 23.1 & 7.7 \\
Development of critical thinking & 4.04 & 0.662 & 80.8 & 19.2 & 0.0 \\
Respect and protection of & 4.15 & 0.834 & 80.8 & 15.4 & 3.8 \\
environment & 3.96 & 0.999 & 77.0 & 15.4 & 7.6 \\
Improvement of society's welfare & 4.00 & 0.849 & 80.7 & 11.5 & 7.7 \\
Ability to follow lifelong learning & 3.88 & 0.766 & 65.4 & 34.6 & 0.0 \\
Communication skills & 3.92 & 0.688 & 73.0 & 26.9 & 0.0 \\
Interpersonal skills & & & & &
\end{tabular}

$S D^{*}=$ Standard Deviation

It is clear that all items under competencies, knowledge, skills, attitudes gained by student-teacher were highly rated by tutors. After completing ISC, student-teachers seem to develop both their critical thinking skills as well as respect and protection of environment at great extend as it was reported by $80.8 \%$ of participated science tutors. These two highly rated skills and ability have been followed by student-teachers' ability to follow lifelong learning at rate of $80.7 \%$ and improvement of society's welfare at $77.0 \%$. Moreover, interpersonal skills, adequate teaching skills were equally rated at $73.0 \%$ while communication skills and scientific inquiry were rated at $65.4 \%$ and $69.3 \%$ respectively. Briefly, most of other competencies, skills, knowledge and attitudes were highly rated except communication skills and problem solving skills that were poorly rated. However, it may be noted that these skills are among the top skills needed by graduates of science in the workplace (Van Heuvelen, 2001; Uwizeyimana, Yadav, Musengimana, \& Uwamahoro, 2018).

Science tutors' perceptions about challenges for ISC implementation

While responding to questionnaire, some challenges were rated by science tutors as big challenges to the implementation of ISC including tutors' heavy workload, inappropriate contact hours allocated to teaching ISC from year 1 to year 3, lack of teacher's guide and textbooks for integrated 
Tutors' perceptions about science curriculum reforms and challenges for their implementation in Teacher Training Colleges in Rwanda

C. Kanamugire, L.L. Yadav and A. Mbonyiryivuze

science subject, lack of science laboratory, lack of provision of in-service training to teachers, and lack of adequate laboratory equipment. The summary of findings on science tutors' perceptions about some challenges is reported in Table 5.

Table 5: $\quad$ Science tutors' perceptions about challenges for effective implementation of ISC

\begin{tabular}{|c|c|c|c|c|c|}
\hline \multirow[b]{2}{*}{ Challenges } & \multirow[b]{2}{*}{ Mean } & \multirow[b]{2}{*}{ SD } & \multicolumn{3}{|c|}{ Percentage } \\
\hline & & & Agree & Neutral & Disagree \\
\hline $\begin{array}{l}\text { Contact hours allocated to teaching integrated } \\
\text { science curriculum from year1 to year } 3 \text { are not } \\
\text { appropriate* }\end{array}$ & 3.85 & 1.120 & 77.0 & 0.0 & 23.1 \\
\hline Teachers have a heavy workload* & 3.88 & 0.864 & 80.7 & 7.7 & 11.5 \\
\hline TTC library is well equipped & 2.88 & 1.395 & 38.5 & 15.4 & 46.1 \\
\hline $\begin{array}{l}\text { Teacher's guide and textbooks for integrated } \\
\text { science subject are available }\end{array}$ & 2.27 & 1.079 & 15.3 & 15.4 & 69.3 \\
\hline Science laboratory is available & 2.77 & 1.728 & 42.3 & 3.8 & 53.9 \\
\hline Science equipment are adequate & 2.54 & 1.529 & 26.9 & 15.4 & 57.7 \\
\hline Computers for teachers are available & 3.38 & 1.416 & 50.0 & 19.2 & 30.7 \\
\hline Computers for learners are available & 3.73 & 1.079 & 57.7 & 26.9 & 15.4 \\
\hline The school is connected to the internet & 4.08 & 1.197 & 80.8 & 7.7 & 11.5 \\
\hline School leadership provides support to tutors & 3.65 & 1.294 & 65.4 & 11.5 & 23.1 \\
\hline There is provision of in-service training to tutors & 2.73 & 1.185 & 26.9 & 26.9 & 46.2 \\
\hline Tutors are well motivated & 3.23 & 0.992 & 38.4 & 34.6 & 26.9 \\
\hline $\begin{array}{l}\text { I have good mastery of the content of } \\
\text { the integrated science curriculum }\end{array}$ & 3.81 & 0.849 & 80.7 & 11.5 & 7.6 \\
\hline $\begin{array}{l}\text { I feel difficulty to use English as a medium of } \\
\text { Instruction* }\end{array}$ & 2.00 & 0.894 & 17.7 & 15.4 & 77.0 \\
\hline $\begin{array}{l}\text { Students face difficulty to follow lessons } \\
\text { delivered in English* }\end{array}$ & 2.73 & 1.343 & 30.8 & 11.5 & 57.7 \\
\hline $\begin{array}{l}\text { There is good collaboration among teachers } \\
\text { in preparing a scheme of work and lesson plans }\end{array}$ & 3.88 & 0.864 & 73.1 & 19.2 & 7.7 \\
\hline
\end{tabular}

* Negative statements

Tutors' heavy workload was perceived by tutors as challenge at rate of $80.7 \%$ while inappropriate contact hours allocated to teaching ISC from year 1 to year 3 was rated at $77.0 \%$. Moreover, science tutors rated the absence of teacher's guide and textbooks for integrated science subject, inadequate of science laboratory equipment, the absence of science laboratory, the lack of provision of in-service training to tutors and lack of well-equipped library at $69.3 \%, 57.7 \%, 53.9 \%$, $46.2 \%$, and $46.1 \%$ respectively.

Findings on challenges related to a heavy workload and provision of in-service training to tutors are in good agreement with the obtained results while conducting a survey on challenges hindering the implementation of integrated curriculum in China by the Hong Kong Department of Curriculum and Instruction (Harrell, 2010).

While probing challenges that science tutors face while implementing ISC through interview, we found that the results are consistent with those obtained through questionnaire about science tutors' perceptions. In addition to the above mentioned challenges, inexistency or insufficiency of instructional resources, lack of manuals for science experiments, insufficiency of reference books 
for some topics and a weak internet connection have also been highlighted during interviews. The challenge of inexistency or insufficiency of instructional resources include lack of science laboratories, lack of laboratory equipment, lack of textbooks and teacher's guides and audio-visual equipment, lack of manual for science experiments, insufficiency of reference books for some topics and a weak internet connection.

Other researchers have also reported that teachers complained about limited teaching resources, lack of guidelines in terms of how to improve teaching, learning and assessment activities and heavy workload of teachers (Gobingca, Athiemoolamand, \& Blignaut, 2017). It has also been reported that inadequate resources, lack of human capacity, lack of skills and knowledge and lack of pre-planning on new curriculum development affect teaching of science (Lizer, 2013). The need of Rwandan TTCs to be well equipped with textbooks and reference books related to curriculum, laboratory materials and internet connection have also been recommended to improve the quality of teaching and learning process (Uworwabayeho \& Muhire, 2016).

Findings from interview reveals that in addition to a very large number of students in a class in some TTCs, some science tutors having inadequate skills to teach ISC do not feel comfortable to teach it. One can argue that science tutors' low rating of periods allocated to most of topics under ISC as sufficient is linked with their experience of difficulties related to mastery of the content which directly impacts their rating. This judgment of inadequacy of periods allocated to different topics can also be linked with specialization or teachers' expertise as pointed out by Werner (1991). The same author claimed that teaching an integrated curriculum may conflict with the teacher's sense of expertise. In assuming that academic preparation is an assumption of a successfully delivered integrated curriculum, Werner (1991) recognizes that it is difficult for teachers to deliver content outside their area of expertise and this will most likely not promote student achievement (Werner, 1991). Moreover, the issue of integration was reported to become much complex as during the curriculum integration process, secondary school teachers see themselves as subject specialists trained only to teach one or two subject areas (Venville, Wallace, Rennie, \& Malone, 2002).

Science tutors' perceptions about factors affecting the implementation of ISC in TTCS

This study reveals tutors' perceptions about some factors influencing the implementation of ISC in TTCs. Here, only five factors and their respective discussions are presented starting from science tutors' level of involvement in designing ISC, their level of understanding of the general objectives of ISC and their level of confidence to teach topics under the content of ISC. Science tutors' judgment on the adequacy between numbers of periods allocated to teach each topic under the content of ISC and their participation in in-service training related to ISC are also discussed.

\section{Science tutors' level of involvement in designing ISC for TTCs}

Teachers' involvement in curriculum design and development has been reported to be essential for its successful implementation by different researchers (Mbonyiryivuze, Kanamugire, Yadav, \& Ntivuguruzwa, 2018). Therefore, the level of science tutors' involvement in designing of ISC for TTCs has been investigated. The study reveals that out of 26 science tutors participated in the study, only $2(7.7 \%)$ have been involved in the designing of the ISC. These two science tutors involved in designing of the ISC argued that their involvement was very useful and of great value. They also showed their eagerness to be involved in designing ISC in future. This finding is in agreement with the research that has shown that change cannot be well implemented without the 
Tutors' perceptions about science curriculum reforms and challenges for their implementation in Teacher Training Colleges in Rwanda

C. Kanamugire, L.L. Yadav and A. Mbonyiryivuze

involvement of teachers (Lumpe, Haney, \& Czeniak, 1998). The more teachers value their involvement in designing the curriculum, the more they will play a key role in its implementation.

Science tutors' level of understanding of the general objectives of ISC

Science tutors level of understanding of ISC general objectives can affect strongly their implementation of this curriculum. Therefore, it is necessary for all science tutors teaching in TTCs to have a high level of understanding for ISC general objectives. The obtained results about science tutors' level of understanding of the general objectives of ISC was highly rated at 88.5\% (with $73.1 \%$ for high level and $15.4 \%$ for very high level). The average level was rated at $11.5 \%$. Objectives allow instructors to set up measures and evaluation tools. It also allows students and instructors to determine what is to be accomplished, a way to determine what should be taught, and a way to measure accomplishment. Mager (1975) explained further reasons of using objectives including helping in selecting or designing instructional material, knowing what was achieved and how it was achieved, planning how to assess the success of instruction and how to organize student efforts and activities for accomplishment of instructional intent (Mager, 1975; Bantwini, 2010).

Science tutors' level of confidence to teach topics under the content of ISC

Teachers' confidence to teach certain topics in a curriculum plays a valuable role for its implementation. Therefore, obtained findings while investigating science tutors' level of confidence to teach topics under the content of ISC shows that the highest rated topic was Introduction to integrated science and measurements with $96.2 \%$. This topic was followed by two other topics which are Materials and structure as well as Air and water rated by science tutors at $84.7 \%$ and $84.6 \%$ respectively. Organic chemistry, and Plant and animal life were also other two topics that were highly rated with level of confidence of $77.0 \%$ and $73.1 \%$ respectively. Forces and motions, Electricity and magnetism as well as Health and hygiene are three topics which were rated at lower level of confidence of $61.6 \%$. This was an indication that most science tutors experienced difficulties to teach these topics. Other topics that science tutors experience difficulties to teach and that were the lowest rated are Light and heat as well as Earth in space. These two topics were rated at percentage of science tutors' level of confidence of $57.7 \%$ and $50 \%$. A significant number of tutors showed reservation in their level of confidence in teaching Earth in space topic. Some science tutors, even those with a long experience in teaching experienced some difficulties to teach this topic effectively as this topic of Earth and space was newly introduced in the ISC. Despite science tutors' confidence to teach ISC, they raised some important challenges hindering its effective implementation including lack of adequate facilities, instructional resources such as textbooks, teacher's guides and laboratory equipments and the need to be supported through in-service training.

Based on the above findings, topics which scored low averages are related to physics and crosscutting domains. The topic to score the least average is Earth in space. This topic was not taught in the separate curricula used before the introduction of ISC and science tutors are likely to experience difficulties while teaching it. Difficulties experienced by science tutors while teaching some topics may be explained basing on Werner (1991) who claimed that teaching an integrated curriculum may conflict with the teacher's sense of expertise. While Werner (1991) assumes that academic preparation is an assumption of a successfully delivered integrated curriculum, he recognizes that it is difficult for teachers to deliver content outside their area of expertise and this will most likely not promote student achievement (Werner, 1991). 
African Journal of Educational Studies in Mathematics and Sciences Vol..., 2019

\section{Science tutors' judgment of periods allocated to teaching each topic under the content of ISC}

The way teachers judge the adequacy of number of periods allocated to teaching each topic under the content of curriculum has a considerable impact on that curriculum implementation. Therefore, it is better to look at science tutors' judgment on the adequacy of periods allocated to teaching each topic under the content of ISC in TTCs as one factor influencing its implementation. The topic that have been highly rated were Introduction to integrated science and measurements, Plant and animal life, Materials and structure, Forces and motions, Electricity and magnetism, Light and heat, Health and hygiene, Air and water, Earth in space and Organic chemistry.

The obtained results about how science tutors judged the adequacy of number of periods allocated to teaching each topic under the ISC are reported below. The topic of Air and water was rated with the highest rate of $65.5 \%$ followed by Introduction to integrated science and measurements topic rated at $57.7 \%$. Earth in space was rated at 50.0\%. Other topics which were rated by science tutors below 50\% are as follows: Electricity and magnetism was rated at $34.6 \%$. Moreover, Forces and motions and Light and heat were equally rated at 30.8\%. Materials and structure; Health and hygiene, and Plant and animal life were equally rated at $23.1 \%$ while the least rated at $23.0 \%$ was Organic chemistry.

We found that most of topics were rated with low mean and percentages of sufficiency. The high rated topic in terms of sufficiency is Introduction to integrated science and measurements with a percentage of sufficiency of $57.7 \%$ while the least rated is organic chemistry with a percentage of sufficiency of $23.0 \%$. One can argue that science tutors' low rating of periods allocated to most of topics under ISC as sufficient is linked with their experience of difficulties related to mastery of the content which directly impacts their rating. This judgment of inadequacy of periods allocated to different topics can also be linked with specialization or teachers' expertise as pointed out by Werner (1991). Moreover, the issue of integration was reported to become much complex as during the curriculum integration process, secondary school teachers see themselves as subject specialists trained only to teach one or two subjects areas (Venville, Wallace, Rennie, \& Malone, 2002).

\section{Science tutors participation in in-service training related to ISC}

It has been reported that inadequate resources, lack of human capacity, lack of skills and knowledge and lack of pre-planning on new curriculum development affect teaching of science (Lizer, 2013). Our finding showed clearly that science tutors expressed lack of in-service training in different aspects of the ISC while they are the key persons to implement it. In fact, science tutors showed that they are not satisfied with in-service training as it was found from their response. The importance of in-service training has been highlighted by many authors as a key factor to supporting reforms. In any reform, teachers will need to be trained and supported (Lewin, 1992; Lizer, 2013). In fact, student-teachers trained by these science tutors will be equipped with adequate knowledge, competencies, skills and attitudes to teach Science and Elementary Technology (SET) at primary school level.

\section{Availability of instructional resources}

The implementation of a new curriculum can mostly be influenced by availability of instructional resources. Lizer (2013) found that lack of resources impact negatively on the implementation of curricular reform in teaching and learning science (Lizer, 2013). It was also stressed by Cunningham (2018) that instructional materials need to be developed and put in place before the 
Tutors' perceptions about science curriculum reforms and challenges for their implementation in Teacher Training Colleges in Rwanda

C. Kanamugire, L.L. Yadav and A. Mbonyiryivuze

new curriculum is introduced. Moreover, the lack of adequate of instructional resources hinders meaningful teaching based on curriculum reforms (Bantwini, 2010; Minjeong \& Youl-Kwan, 2013; Gobingca, Athiemoolamand, \& Blignaut, 2017). Therefore, adequate and enough instructional resources should be available for effective implementation of curriculum. This section highlights the obtained results while studying science tutors rating of level of availability of instructional resources for ISC. Instructional resources rated by science tutors above $50 \%$ were considered to be adequate; those rated by a considerable number of science tutors were considered to be inadequate while the remaining resources were rated as almost non-existent.

The availability of curriculum of integrated science subject was rated to be adequate at $76.9 \%$. The appropriate chalkboards/white boards/smart boards, and internet connections were equally rated at $65.4 \%$. Besides, resource rooms, TTCs' library, and tutors' computers were rated to be adequate at $61.5 \%, 57.7 \%$ and $53.8 \%$ respectively. Even though the above listed resources were rated as adequate, the percentage of adequate is still low. There is still a room for improvement to increase the level of adequacy for these resources/materials.

Among resources that have been rated to be inadequate by science tutors were teaching aids, students' computers, and laboratory equipment which are rated at 53.8\%, 50.0\% and $42.3 \%$ respectively. Moreover, digital content ( $\mathrm{CD}-\mathrm{ROMS}$, modelling) and other online resources for simulation, animation, LCD projectors as well as science laboratories have been rated to be inadequate at $38.5 \%, 34.6 \%$ and $23.1 \%$ respectively.

Other resources have been rated by science tutors as almost nonexistent and they include laboratory technician with at $88.5 \%$ and practical manual for science experiments at $69.2 \%$. It was also found that science textbooks for students related to the ISC and teacher's guide are not yet elaborated. Moreover, $38.5 \%$ of science tutors who were involved in the research responded that they don't have science laboratories.

In all TTCs, even those not included in the research, resource rooms are under construction with funding from Voluntary Services Overseas (VSO). This will be an added value to teaching resources rated as inadequate. It has been argued that materials help teachers to initiate and sustain reform in science education as they are concrete, tangible vehicles for embodying the essential of a reform (Powell \& Anderson, 2002). However, curriculum materials do not by themselves generate changes in the classroom; they are tools that teachers can use to act out changes.

\section{Strategies to overcome challenges hindering the implementation of ISC}

This section reports science tutors' perceptions about potential strategies to overcome challenges that hinder the effective implementation of ISC. The proposed strategies include involvement of science tutors in designing integrated science curriculum, development of textbooks and teacher's guide for integrated science curriculum, organization of in-service training for science tutors on teaching methods, assessment of the curriculum, training of science tutors in English for science teaching, provision of an adequate number of qualified tutors and adequate facilities such as wellequipped libraries and laboratories in TTCs.

The results show that almost all science tutors agree with proposed strategies as it was shown by their answers. Their level of agreement varies from $80.8 \%$ to $96.2 \%$. Science tutors' desire to be involved in designing ISC, the provision of adequate facilities and the development of textbooks and teacher's guide for integrated science curriculum were highly rated strategies by science tutors. The desire for tutors to be involved in designing and implementing a curriculum reform was also 
reported in research claiming that teachers are more likely to assume responsibility for curriculum rather than attributing it to others when involved in planning and implementing reform (Datnow \& Castellano, 2000).

The findings reported in the Table 6 are science tutors' perception of potential strategies to overcome challenges hindering effective implementation of ISC.

Table 6: $\quad$ Science tutors' perception about potential strategies to overcome challenges hindering effective implementation of ISC

\begin{tabular}{|c|c|c|c|c|c|}
\hline \multirow[b]{2}{*}{ Strategies to overcome challenges } & \multirow[b]{2}{*}{ Mean } & \multirow[b]{2}{*}{ SD } & \multicolumn{3}{|c|}{ Percentage } \\
\hline & & & $\begin{array}{l}\text { Great } \\
\text { extent }\end{array}$ & $\begin{array}{l}\text { Some } \\
\text { extent }\end{array}$ & $\begin{array}{l}\text { Little } \\
\text { extent }\end{array}$ \\
\hline $\begin{array}{l}\text { Science tutors should be involved in designing } \\
\text { integrated science curriculum }\end{array}$ & 4.81 & 0.634 & 96.2 & 0.0 & 3.8 \\
\hline $\begin{array}{l}\text { Textbooks and teacher's guide for integrated science } \\
\text { curriculum should be developed }\end{array}$ & 4.81 & 0.491 & 96.1 & 0.0 & 3.8 \\
\hline $\begin{array}{l}\text { Organization of in-service training for science tutors } \\
\text { on teaching methods, assessment of the curriculum }\end{array}$ & 4.58 & 0.758 & 93.3 & 3.8 & 3.8 \\
\hline $\begin{array}{l}\text { Training of science tutors in English for science } \\
\text { teaching }\end{array}$ & 4.12 & 1.107 & 80.8 & 7.7 & 11.5 \\
\hline $\begin{array}{l}\text { TTCs should be provided with an adequate number } \\
\text { of qualified tutors }\end{array}$ & 4.62 & 0.637 & 92.3 & 7.7 & 0.0 \\
\hline $\begin{array}{l}\text { TTCs should be provided with adequate facilities } \\
\text { such as well equipped libraries, laboratories, etc. }\end{array}$ & 4.65 & 0.846 & 96.1 & 0.0 & 3.8 \\
\hline
\end{tabular}

The organization of in-service training for science tutors on teaching methods and assessment of the curriculum and provision of an adequate number of qualified tutors are other strategies which were highly rated. The organization of in-service training for science tutors was rated with a percentage of agreement of $93.3 \%$ while provision of an adequate number of qualified tutors was rated with a percentage of $92.3 \%$. Fullan (1991) claimed that for addressing specific concern and conceptual understanding for continual use of a new curriculum at early stage of implementation, the organization of in-service training is an essential support to teachers/tutors (Fullan, 1991). The provision of an adequate number of qualified tutors is a must given that only $61.5 \%$ of science tutors hold a Bachelor degree with education on one hand and to fulfill the requirements for tutors to teach in TTCs on the other hand (MINEDUC, 2014). The least rated strategy was the training of science tutors in English language for science teaching. Although, the issue of English language as a medium of instruction was not raised as a serious challenge for ISC implementation, it can fall into the need for science tutors to update their language skills through in-service trainings. All listed strategies have also been proposed by science tutors during interview.

\section{Conclusions}

The study revealed that teaching staff was generally youthful. It was found that tutors qualification was problematic as only $7.7 \%$ of science tutors met required criteria to teach in TTCs. Despite the study findings that most science tutors were in agreement with reforms that occurred in science curriculum for TTCs, some of them were not happy on the structure of ISC. Moreover, science tutors need to be trained through in-service training, workshops and study tours. Generally, the study found that students-teachers gained most competencies, skills, knowledge and attitudes after completing ISC even though communication skills and problem solving skills that are considered 
Tutors' perceptions about science curriculum reforms and challenges for their implementation in Teacher Training Colleges in Rwanda

C. Kanamugire, L.L. Yadav and A. Mbonyiryivuze

to be important skills needed by graduates of science in the workplaces were poorly rated by participated science tutors. Tutors' perceptions about some challenges and factors hindering effective implementation of ISC as well as their perceptions about some proposed strategies to overcome the challenges have also been discussed in this paper.

\section{Recommendations}

It is recommended that science tutors in TTCs should be involved actively in designing and development of ISC. Some training on the philosophy of shifting from separate subjects to integrated topics should be provided for these tutors. There is an imperative need that all TTCs should be provided with science tutors qualified in teaching ISC. In order to ease ISC implementation in TTCs, addressing these challenges is needed. Therefore, different stakeholders such as Ministry of Education, Rwanda Education Board, and University of Rwanda-College of Education should address those challenges and provide further supports in terms of improvement of facilities, instructional resources, and in-service training. The development of ISC related textbooks and teacher's guide is needed for harmonization. Moreover, regular in-service trainings for science tutors in TTCs are needed to equip them with update knowledge in terms of teaching methods, assessment techniques, and ICT skills.

\section{References}

Abudu, A. M., \& Mensah, M. A. (2016). Basic school teachers' perceptions about curriculum design in Ghana. Journal of Education and Practice, 7 (19), 21-29.

Atkin, J. M. \& Black, P. (2010). Handbook of research on science education: History of science curriculum reform in the United States and the United Kingdom. New York, USA: Routledge.

Bantwini, B. D., (2010). How teachers perceive the new curriculum reform: Lessons from a school district in the Eastern Cape Province, South Africa. International Journal of Educational Development, 30, 83-90.

Cohen, L., Manion, L., \& Morrison, K. (2012). Research methods in education (6 ed.). London, UK: Routledge.

Cunnigham, R. (2018). UNICEF Think piece series: Curriculum reform. UNICEF Eastern and Southern African Region Office, Nairobi.

Datnow, A., \& Castellano, M. (2000). Teachers' responses to success for all: How beliefs, experiences, and adaptations shape implementation. American Educational Research Journal, 37 (3), 775-779.

Dillon, J. (2009). On scientific literacy and curriculum reform. International Journal of Environmental \& Science Education, 4 (3), 201-213.

Erduran, S. \& Msimanga, A. (2014) Science curriculum reform in South Africa: Lessons for professional development from research on argumentation in science education. Education as Change, 18 (1), S33-S46.

Fullan, M. (1991). The new meaning of educational change (2nd Edition ed.). Great Britain: Cassel Educational Limited. 
African Journal of Educational Studies in Mathematics and Sciences Vol..., 2019

General Inspectorate of Education, 2. (2009). Quality standards in education for nursery, primary and secondary schools in Rwanda. Rwanda. Kigali: General Inspectorate of Education.

Gobingca, B. Z., Athiemoolamand, L., \& Blignaut, S. E. (2017). Teachers' perceptions of the factors affecting the implementation of the national curriculum statement in the Mthatha education district. International Journal of Educational Sciences, 18 (1-3), 191-199.

Harrell, P. (2010). Teaching an Integrated Science Curriculum. Linking teacher knowledge and teaching assignments. Teacher Education, 19 (1), 146-148.

Kabita, D. N., \& Ji, L. (2017). The why, what and how of Competency-Based Curriculum reforms: The Kenyan experience. Nairobi, Kenya: IBE-UNESCO.

Keys, P. M. (2003). Primary and secondary teachers shaping the science curriculum: The influence of teacher knowledge. A thesis submitted in fulfillment of the requirements for the degree of Doctor of Philosophy. USA: Queensland University of Technology.

KIE. (2011). Integrated Science Curriculum for Teacher Training Colleges. Option: Science and Mathematics. Kigali: Kigali Institute of Education.

Lewin, K. (1992). Science education in developing countries: issues and perspectives for planners. IIEP research and studies programme. The development of human resources: the provision of science education in secondary schools. Paris: UNESCO/ International Institute for Education Planning.

Lizer, T. L. (2013). The impact of the curriculum change in the teaching and learning of science: A aase study in under-resourced schools in Vhembe district: Thesis. University of South Africa.

Lumpe, A., Haney, J., \& Czeniak, C. (1998). Science teacher beliefs and intentions to implement science-technology-society (STS) in the classroom. Journal of Science Teacher Education, $9(1), 1-24$.

Mager, R. (1975). Preparing instructional objectives (2nd Edition ed.). Belmont, CA: Lake Publishing Co.

Mbonyiryivuze, A., Kanamugire, C., Yadav, L. L., \& Ntivuguruzwa, C. (2018). Reforms in science curricula in last six decades: Special reference to physics. African Journal of Educational Studies in Mathematics and Sciences, 14, 153-165.

Meltzer, D., \& Otero, V. K. (2015). A brief history of physics education in the United States. American Journal of Physics, 83 (5), 447-458.

MINEDUC. (2007). Teacher Development and Management Policy in Rwanda Kigali. Kigali: Ministry of Education.

MINEDUC. (2014). Kigali: Ministry of Education.

MINEDUC. (2009). Inyandiko igaragaza amasomo yigishwa mu mashuri abanza n'ayisumbuye. Kigali: MINEDUC.

MINEDUC. (1997). Study of the education sector in Rwanda. Kigali: MINEDUC. 
Tutors' perceptions about science curriculum reforms and challenges for their implementation in Teacher Training Colleges in Rwanda

C. Kanamugire, L.L. Yadav and A. Mbonyiryivuze

Minjeong, P. \& Youl-Kwan, S. (2013). Teachers' perceptions of the recent curriculum reforms and their implementation: What can we learn from the case of Korean Elementary Teachers? Asia Pacific Journal of Education, 33 (1), 15-33.

Ndihokubwayo, K. (2017). Investigating the status and barriers of science laboratory activities in Rwandan teacher training colleges towards improvisation practice. Rwandan Journal of Education, 4 (1), 47-54.

Ndihokubwayo, K., Uwamahoro, J., \& Ndayambaje, I. (2018). Use of improvised experiment materials to improve Teacher Training College students' achievements in Physics, Rwanda. African Journal of Educational Studies in Mathematics and Sciences, 14, 71-84.

Park, D-Y., (2006). Curriculum reform movement in the US - Science Education. The 1st Pacific Rim Conference on Education, Hokkaido University of Education: Hokkaido, Japan.

Powell, J., \& Anderson, D. R. (2002). Changing teachers' practice: curriculum materials and science education reform in the USA. Studies in Science Education, 37 (1), 107-136.

REB. (2015). Competence-Based Curriculum: Framework pre-primary to upper secondary. Kigali: REB.

Uwizeyimana, D., Yadav, L.L., Musengimana, T., \& Uwamahoro, J. (2018). The impact of teaching approaches on effective physics learning: an investigation conducted in five Secondary Schools in Rusizi District, Rwanda. Rwandan Journal of Education, 4 (2), 414.

Uworwabayeho, A., \& Muhire, I. (2016). Statistical analysis of TTC students' performance in the examinations for the award of a primary teacher education certificate. The Rwandan Journal of Education, 3 (2), 51-62.

Van Heuvelen, A. (2001). Milikan Lecture 1999: The workplace, student minds, and physcis learning systems. American Journal of Physics, 69 (11), 1139-1146.

Venville, G., Wallace, J., Rennie, L., \& Malone, J. (2002). Curriculum integration: Eroding the high ground of science as a school subject. Studies in Science Education, 37 (1), 43-83.

Werner, W. (1991). Defining Curriculum policy through slogans. Journal of Education Policy, 6 (3), 225-238. 